Die Auseinandersetzung mit Aufständen in schwachen Staaten mag zwar ein Konfliktszenario sein, das im 21. Jahrhundert wieder an Bedeutung gewinnt. Die Antwort sollte aber nicht so ausfallen wie in Afghanistan oder im Irak. Gefragt sind vielmehr Gründlichkeit in der Lageanalyse, Bescheidenheit in der Zielsetzung und Zurückhaltung mit militärischer Intervention. Wenn aber eine komplexe Intervention unter Einschluss militärischer Mittel durchgeführt wird, sollte sie einer nachhaltigen friedenspolitischen Logik folgen und nicht einer machtpolitischen, d.h. die langfristige Entwicklung des Ziellandes sollte
Vorrang haben vor militärischen („war on terror“), geostrategischen (Kontrolle eines Raumes), ideologischen (regime change) oder bündnispolitischen (Rolle in und Zukunft der NATO) Erwägungen. Grundsätzlich aber gilt für jede Art des Krisenmanagements: „Not every game is worth playing, and sometimes the best way to win is not to play at all." 69

69 Anthony Cordesman, Rethinking the Challenge of Counterinsurgency Warfare, CSIS Working Notes, 7. November 2005, S. 3.

\title{
With Enough Nails: Canadian Coin in Kandahar
}

\author{
Richard Roy*
}

Abstract: In 2009 Canada was in the midst of waging a counterinsurgency campaign in Kandahar province. That it was involved in a counterinsurgency was not clear from its initial deployment there in 2006. Since then Canada has made enormous strides in its capabilities to conduct these types of operations. It has improved in several key ways. This includes how it collects intelligence, how it trains the Afghan security forces, how it has re-focussed its efforts to better protect the population, and how it has improved unity of effort at the operational and strategic level. Canada has learned much about counterinsurgency and particularly the relevance of the comprehensive approach in these types of operation.

Keywords: Counterinsurgency, Canada, Kandahar, intelligence, training, unity of effort Counterinsurgency, Kanada, Kandahar, Aufklärung, Training, gemeinsames Vorgehen

\section{Introduction}

$\mathrm{I}$ $\mathrm{n}$ an operational environment, especially a complex one, small things can dramatically alter our capacity to influence events. There is a poem that hints at the importance of even the tiniest, most common element of a system.

For want of a nail the shoe was lost,

For want of a shoe the horse was lost,

For want of a horse the rider was lost,

For want of a rider the battle was lost,

For want of a battle the kingdom was lost,

And all for the want of a horseshoe nail. ${ }^{1}$

In Afghanistan in 2009, Canada did not lack for nails. The system functioned well yet many small things had a great influence on how the campaign unfolded.

This paper outlines how Canada conducted its counterinsurgency campaign in Afghanistan during the better part of 2009. It will describe some of the general parameters that must be considered in a campaign of this nature. This will be followed by a brief discussion of how Canada has improved its response in this type of campaign. An overview will then be given of how Canada has performed in some of the core areas

\footnotetext{
* Richard Roy is a Lieutenant-Colonel serving in the Canadian Forces. Currently, he is the national desk officer for the comprehensive approach. He is working on his doctorate through Queen's University in Kingston, Ontario. His topic is the importance of population control measures in small wars. 1 See http://en.wikipedia.org/wiki/For_Want_of_a_Nail_(proverb)
}

that contribute to success in a counterinsurgency: intelligence, training local security forces, separating the population from the insurgent and developing unity of effort. This will not be purely a military discussion as insurgencies are rarely solved by military force alone.

\section{The Initial Challenge}

To begin, it is important to understand the nature of a conflict and how it might transform. The wise advice of Clausewitz to statesmen that they must be aware of the type of conflict in which they are choosing to engage remains applicable today. A nation commits its forces, trained in types of operations for preconceived scenarios of national import, with expectation of success, though the immediacy of success is time and again overestimated. Was it clear as the allied supported Northern Alliance pushed the Taliban out of Kabul and in the follow-on operations in the southern provinces how this conflict would evolve? Was it clear that initial strokes of Operation Enduring Freedom would come so close to complete victory but miss the mark? Was it clear that the Taliban would be able to reconstitute and re-invent itself? This lack of clarity in the conflict dynamics in Afghanistan, the fog of war, has hampered the progress of the campaign there. ${ }^{2}$

2 Some like Geoffrey Shaw propose that we have not as yet structured our
campaign to really counter the Taliban. See Geoffrey Shaw, "Afghanistan's campaign to really counter the Taliban. See Geoffrey Shaw, "A 
Some clarity has emerged slowly in response to geographical deployments, influences of the opposition and to the improvement and refinement of counterinsurgency prescriptions for success. First, the Canadian contribution was conditioned by where it was deployed. The first Canadian elements sent to Kandahar in 2002 helped secure the former Taliban stronghold and aid in the pursuit of a seemingly beaten foe. Next, the Canadian contingent spent several years establishing security, stability and state capacity in Kabul. From 2006 Canada returned to the midst of the contentious South. The dangers, risks and responses required in these areas differ not only due to geographic peculiarities - urban, vineyard, canal, etc - but to the presence, determination and organizational capabilities of the common adversary. Though a type of counterinsurgency is being fought today it cannot be generalized or presumed that this nature of operation was a Canadian focus from the first instant. ${ }^{3}$

Second, the opponent and their adaptive responses have a tremendous bearing on the countering tactics and strategies. The resurgent Taliban of today are vastly different from those desperately fleeing for the Pakistani border in the early months of the conflict. Further, the Taliban are not as homogeneous as often indicated; David Kilcullen's inference of the accidental guerrilla is generally accurate. ${ }^{4}$ As more substantial understanding of the networks of opponents that existed in the operational space was developed, the ability to counter them improved, but given the highly adaptable nature of the foe response could not remain static.

Finally, as the campaign has progressed and counterinsurgency thinking has been refined, the importance of the local population has been re-discovered and re-defined. Early on they may have been considered secondary, but now, in proper counterinsurgency fashion, they have become the centre piece of the campaign.

In conditions like these, Canadian efforts, like those of many other nations, are and must be constantly modified. It was therefore hard to gauge exactly when we could determine we were deeply and clearly contesting an insurgency and how best to respond.

Resolving complex situations like Afghanistan can be approached in two ways, but a shared vision is crucial for success. Complexity can be addressed by either top-down or bottom-up methodologies. From a top-down perspective, complexity theory suggests that the starting point is to properly frame the strategic problem and then establish a coherent, unified national strategy that supports and aids the host nation. National plans would then be linked and de-conflicted amongst intervening partners ensuring there are no gaps. The aim is for the multitude of nations, partners, organizations and agencies involved to develop a shared, unified vision of their common objectives that can be translated into coherent and consistent action from the strategic to the operational level.

3 Janice Gross Stein and Eugene Lang, The Unexpected War: Canada in Kandahar (Toronto: Viking Canada, 2007): 210. Stein suggests that it is obvious that as early as 2005 Canada was involved in an insurgency. The nuances of how the Taliban were conducting their campaign do not support this.

4 David Kilcullen, The Accidental Guerrilla: Fighting Small Wars in the Midst of a Big One (New York: Oxford University Press, 2009).
This process, involving a multitude of actors in the resolution of complex issues, is generally referred to as the comprehensive approach. From a bottom-up perspective, complexity is in no way diminished, but the view is that useful action can only be planned once it is determined what can be feasibly accomplished in each specific locality. ${ }^{5}$ So, while perhaps informed by an overarching strategy, action must be based on pragmatic local knowledge not prescription.

The utility of both approaches hinges on the granularity of the information available and a shared vision of what constitutes victory. Granularity comes with time. We can never fully understand the environment into which we first deploy and this constrains our first tentative solutions. Building on some of the ideas of Robert Mandel, ${ }^{6}$ we often are in the same room and even speaking the same language but advancing different notions of how to achieve our aim, having inconsistent visions of victory. While we should not have expectations of shared functional expertise, nor would it be useful in most cases, we do need a shared vision of what is necessary to resolve the insurgency.

The attention afforded to counterinsurgency as a solution over the past few years has good and bad points. There are good points in examining past campaigns. Valuable lessons can be drawn from them: the importance of security partnerships, of force levels sufficient to atomize oppositional forces, of owning the night, of separating the insurgent from the population, and of establishing effective control, to name a few. The bad points involve the detail of our consideration of past campaigns and the constructs and mechanisms we select for re-use. Casual reference often replaces the detailed study that would point to the true tipping points for some past conflicts. For instance, Karl Hack has argued the British had effectively won the 194860 Malayan Emergency before General Templar was appointed, shedding a different light on influence and importance of his presence to the success of the campaign. ${ }^{7}$

Another error is misconstruing past techniques for modern purposes and here, in particular, the current distortion of "hearts and minds" must be considered. The intent of hearts and minds in Malaya was to encourage the Malayan Chinese to become full member of the Malaya polity, a method to form a shared national identity. Repeatedly today we hear of "cash as a weapon" and the benefits accrued to reconstruction under the rubric of hearts and minds, an inference that if we bribe the locals enough they will support us, a frequently disproved hypothesis. ${ }^{8}$ There are other problems. One is the penchant to refine the definitions of current conflicts (hybrid, 4G, etc.) even as the obvious trends of many past campaigns resurface. For

5 This goes beyond simply a needs assessment towards exploiting what James C. Scott in Seeing Like a State (1998) termed the local's metis.

6 Mandel has pointed to the difficulties of defining post-event victory. It is even more difficult to decide on how to achieve it beforehand. See Robert Mandel, "Defining Postwar Victory," in Understanding Victory and Defeat in Contemporary War, ed. Jan Angstrom and Isabelle Duyvesteyn, 13-45 (New York: Rutledge, 2007).

7 Karl Hack, 'The Malayan Emergency as Counterinsurgency Paradigm', Journal of Strategic Studies 32 (June 2009): 383-414.

8 For some of the confusion over hearts and minds see Paul Dixon, "'Hearts and Minds'? British Counterinsurgency from Malaya to Iraq," Journal of Strategic Studies 32 (June 2009): 353-381. A better construct of hearts and minds could be based on Benedict Anderson's arguments in Imagined Communities (2006). 
instance, aspects of modern missions are remarkably similar to what the United States experienced in the 1898-1902 Philippine Insurrection: elusive guerrillas, atrocities, nation-building, and intractable foes. ${ }^{9}$ History can therefore provide useful markers if the examples are carefully drawn.

\section{Improving the Canadian Response}

Borrowing from past operations does not explain why Canada has become good at counterinsurgency. The United States has a lengthy historical involvement in small wars. Their Indian Wars, the Philippine Insurrection, the interventions in the Caribbean and even Vietnam ${ }^{10}$ are all feats of arms that have provided some direction despite their cyclical indifference and amnesia usually associated with the study of counterinsurgency. Canada has a much thinner record, principally the Boer War, a good century and more ago, from which to draw. The plain fact though is that Canada produces extremely competent tactical units, the cornerstone of any successful operation. The typical assignment of Canadian troops to the most difficult and contested zones on numerous peacekeeping missions bears out this effectiveness. One step further, the Canadian construct for complex peace support operations, as described in Canadian joint doctrine, shares great similarities with the techniques demanded in a counterinsurgency. ${ }^{11}$ Further, the Canadian Forces codified how they would carry out these types of operation in their own manual, released in December 2008, relatively shortly after they engaged in this for them relatively new discipline. A lively debate has ensued and revisions to the existing manual are now being contemplated.

The Canadian Forces have become better at counterinsurgency by exploiting to the fullest extent possible learning opportunities in three main areas. First, our close partnership with the United States has enabled us to place instructors and advisors within the American military educational system. For instance, a key curriculum developer at the Canadian Forces College previously taught military operations other than war while serving at Fort Leavenworth and a Canadian lieutenantcolonel is on staff at the Marine Corps Small War Center. Lacking a Canadian counterinsurgency centre of excellence, these individuals have facilitated the flow of current best practices and ongoing debates back to Canada. ${ }^{12}$ Second, the enthusiasm of senior officers to learn about counterinsurgency has markedly improved. Reading lists and earmarked books now clutter many offices. Finally, since 2006, the Canadian Army has taken major steps to ensure that lessons are captured effectively on operations and translated into the necessary modifications in training and practice. Lesson-learn staffs are embedded in all major deployed elements where they monitor

9 See Brian Linn, The U.S. Army and Counterinsurgency in the Philippines War (Yale University Press, 2000) or Stuart Creighton Miller, Benevolent Assimilation: The American Conquest of the Philippines, 1899 - 1903 (Yale University Press, 1982).

10 See Max Boot, The Savage Wars of Peace: Small Wars and the Rise of American Power (New York: Basic Books, 2002).

11 See Department of National Defence, B-GJ-005-307/FP-030 Peace Support Operation, http://www.cfd-cdf.forces.gc.ca/sites/page-eng.asp?page $=3490$.

12 Anthony Fenton, "Canadian Counterinsurgency Manual Reflects US-Canada 'synergy,'” July 11, 2009, http://www.dominionpaper.ca/articles/2770 (accessed February 2, 2010). a wide variety of issues and at times are usefully and ably supported by defence scientists. ${ }^{13}$ These learning opportunities have paid dividends as the Canadian Forces have explored how to improve counterinsurgency performance.

Canada has gleaned a number of crucial lessons from its recent exposure to counterinsurgency campaigning. First, there is a need to be constantly agile and adaptable in feeling your way forward in a complex environment. Not only does a plan not necessarily survive at first contact with the enemy, it may well be completely ineffective in the first place. This agility must be built through information mechanisms that constantly improve the situational awareness of both the geographic and human terrain. Second, regardless of the perceived utility of any instrument of state brought to bear on an insurgency, an enduring solution will remain a political one. It will be qualitative improvements in the political situation as reflected in greater stability versus merely quantitative solutions - more money, for instance - that will dismantle an insurgency. ${ }^{14}$ Finally, you need buy-in from the host nation. Their desires and needs have to be satisfied as identified by them instead of simply projecting Western desires onto proffered programs. ${ }^{15}$ All projects must therefore to a certain degree be planned bottom-up and their political component, the value of the negotiation process and power distribution between local authorities, must be kept fully in view.

The broad parameters of how to win at counterinsurgency are recorded in the classic works and in the many thick military manuals on the subject. Below, four key elements will be examined: intelligence, building local security forces, separating the insurgent from the population, and unity of effort. Intelligence is important to focus operations. It permits precise targeting, ensures efforts are not wasted or dissipated and, most critically, underscores the accumulation of information and knowledge that can re-interject a measure of 'art' into a campaign. Troop ratios are crucial within a counterinsurgency which lends importance to competent local security forces. Building host nation security forces, military and police, increases the ability to flood an area with troops so as to properly clear and hold it. Building viable local forces confers legitimacy onto the host nation government and returns a measure of the ownership of the security problem to them, crucial to a transition plan. Adding them to the force mix in theatre also serves as an economy of force measure for the intervening coalition. Regardless of whether labelled population centric operations or something else, a fundamental component for success in a counterinsurgency is that the population must be separated and protected from the insurgent. Historically, an extensive variety of control measures have been used to drive a wedge between the insurgents and the population, including resettlement, identification cards, rationing and movement restrictions. Finally, unity of effort

13 See Canadian Army Lessons Learned Centre. http://armyapp.dnd.ca/allc-clra/ default_e.asp

14 Peter Pigott, Canada in Afghanistan: The War so Far (Toronto Dundurn Press, 2007), 173. Pigott outlines the unlikelihood of a military solution.

15 The development community has long struggled to actual base its programs on the actual wants of the assisted groups. See William Easterly, The White Man's Burden: Why the West's Efforts to Aid the Rest have done so much Ill and so Little Good (New York: Penguin Books, 2006). 
allows the broad strategic solution for the insurgency to be translated across all actors (horizontally) and to be cascaded across all levels (vertically). For Canada, unity of effort has progressed from the generalities of the 3D approach, to the more coherent whole of government construct, to the much broader and inclusive comprehensive approach. These key elements will be further examined below.

\section{Intelligence}

Canadians have become better at prosecuting the counterinsurgency in Afghanistan as the understanding of the complex nature of the operational environment has matured. This is where well-developed intelligence structures come to the fore. There are inherent complexities in southern Afghanistan, well reflected in a pair of reports from the Institute for the Study of War: Securing Helmund: Understanding and Responding to the Enemy and The Taliban's Campaign for Kandahar. ${ }^{16}$ These reports point out the intricacies of both the physical and the human terrain. To really understand either terrain requires a lengthy commitment. Canadian troops are now bloodily familiar with the vineyards, the fields, the canals and pathways in Kandahar province. The development of a familiarity with the human terrain has been supported by the creation within the formation headquarters of "white intelligence" cells, an organization that concentrates on social networks within the operational area. These cells, having a more detailed and thorough understanding of local dynamics, contribute to a more nuanced planning capability. Given this more sophisticated perspective of the local situation enables planners to design operations and select of courses of actions that do not hazard creating more opponents than friends by contravening cultural norms, that are well linked to the desires of the recipients, and that carefully consider tribal dynamics and the interrelationship between all actors. These cells permit relevant social networks to be studied, monitored, shaped and supported. Canadian performance has therefore improved as knowledge of the conflict environment, its social context and dynamics, has matured.

\section{Training the Afghan Security Forces}

In Afghanistan, the historical importance of police forces in the resolution of insurgencies appears to have been overlooked. Expanded, competent police versus military forces have underpinned many successful counterinsurgencies of which Malaya and Kenya are the most obvious examples. In the 1950s Britain had the luxury of a large, global police establishment to mobilize for emergencies. It is doubtful that modern Western nations have sufficient police capacities to sufficiently recruit for today's campaigns, making the development of indigenous forces even more vital. The value of police even in United Nations mission was only slowly recognized in the mid-1990s and has since become a central component

16 Available from http://www.understandingwar.org/afghanistan-project/publications/reports. of every one. What is unambiguous is that police forces are a complementary institution in the delivery of security in any country. ${ }^{17}$ A failure to adequately reform and train them will prolong any intervention. The problems plaguing the Afghan National Police (ANP) are well recorded: corruption, lowpay, shake-downs etc. ${ }^{18}$ All demand attention. Besides this, determining the proper mix for effective training is crucial: what portion of training should be devoted to community policing, police intelligence procedures or basic survival skills. Even then, pushing out police outposts into lonely, isolated locations, using them as a weak substitute for military troops, detracts from their more important roles. For Canada, civilian police from the Provincial Reconstruction Team (PRT) aid in the mentoring and training of ANP officers in regular police work. Their initiatives have been supplemented by deployed military police elements that have now been organized into a Police Operational Mentoring and Liaison Team (POMLT). While Canada is contributing its part in this important aspect, righting the ANP across Afghanistan will remain a difficult trial.

Another cog in the Canadian transition plan is a trained Afghan National Army (ANA) fully capable of planning, executing and sustaining the counterinsurgency. This training role is assigned to the Operational Mentoring and Liaison Team (OMLT). The OMLT assists in force employment and capability development of the assigned brigade, most recently the 1-205th and its six Kandak battalions. The OMLT helps synchronize ANA operations with those of the coalition forces and seeks to secure combat enablers, such as close air support, fires and medical evacuation, as required. The OMLT has a progressive, tiered set of goals to develop the ANA units: the aim is to advance units from capability milestone 4 (a formed unit incapable of conducting operations) to capability milestone 1 (a unit is fully capable of conducting operations and only requires combat support enablers). In 2009, ANA forces in Kandahar were progressing well at the tactical level but needed more engagement between the operational levels of command and the Government of Afghanistan (GoA). The Canadian OMLT is making a useful contribution to the development of local ANA forces that are deeply committed to the fight, by encouraging them towards rapid improvements in combat effectiveness. ${ }^{19}$

\section{Separating the Population}

The Canadian Task Force in Kandahar in 2009 adopted a more population-centric approach in order to better protect the population. ${ }^{20}$ It re-orientated on securing Kandahar City where $85 \%$ of the population of the province lives. The Canadian Task

17 For the value of police in COIN see Joseph D. Celeski, Policing and Law Enforcement in COIN - the Thick Blue Line, JSOU Report 09-2 (Joint Special Operations University, February 2009).

18 T. Christian Millar, Mark Hosenball and Ron Moreau, "The Gang That Couldn't Shoot Straight," Newsweek, March 29, 2010: 26 -31.

19 Summarized from Colonel D. Burt, OMLT Roto 7 (presentation March 22, 2010).

20 Patrick White, "Canada's Kandahar legacy rests on a shift in strategy, but is there enough time?" Globe and Mail, February 8, 2010, http://www.theglobeandmail.com/news/national/canadas-kandahar-legacy-rests-on-a-shift-instrategy-but-is-there-enough-time/article1417043/ (accessed May 21, 2010). 
Force implemented operational plan KANTOLO, ${ }^{21}$ a multiplephased series of operations (OP KALAYs), ${ }^{22}$ that sought to stabilize Kandahar City and the key villages on its approaches in order to enhance the protection of the population. This sector-by-sector plan mirrored the classical counterinsurgency ink-spot methodology. For each sector, operations were developed and executed in full partnership with Afghan national security forces (ANSF), in close coordination with the GoA and carefully de-conflicted with the other participating Canadian government actors. The goal of each OP KALAY was to establish a permanent presence among the people to solidify security. Living amongst the people facilitated the development of relationships and informal linkages and improved pattern recognition, both important first steps to separating the insurgent from the populace. Persistent presence provided a measure of population control which is perhaps less intrusive than other methods, such as identification cards. Each OP KALAY commenced with action to clear the sector followed by the immediate establishment of platoon houses within the newly secured areas by the special organized Stabilization Company of the PRT. Quick impact stabilisation projects, managed by the Canadian military construction organizations - Specialized Engineering Teams (SET) and Construction Management Organization (CMO) - were quickly launched to demonstrate the intent to further hold and build the sector. At certain transition points, determined as the security situation improved, the military presence was scaled back, the PRT assumed responsibility for project initiation, and where practical and feasible, CMO projects that shaped the conditions for future development projects were handed over to the PRT. As conditions improved in a sector, OP KANTOLO forces would be shifted to the next designated sector. Military presence plus the rapid delivery of tangible projects by the $\mathrm{CMO}$ demonstrated that local conditions had changed and provided a mechanism to negotiate forward with local authorities for their own, better future. In 2009, living amongst the villagers visibly demonstrated to them the Canadian commitment to their security; this materially benefited the campaign.

\section{Unity in the Field - the Development Example}

While highly visible, highly necessary and of proven utility, development, one of the main tools being applied in the contest in Afghanistan, remains difficult to deliver in practice. There is good historical evidence of its utility when correctly applied. For instance, in the 1948-60 Malayan Emergency, following resettlement, the services provided in the "new villages," previously unobtainable, were viewed as a way to entice the relocated Chinese squatters from under the sway of the communist terrorists. The modern, continuing existence of a large number of these "new villages" attests to the benefit of the development programs included in their establishment. Post-independence, the Malayan government retained the Emergency-originated combined command structure so widely written about to deliver rural development to the Malayan

21 For a general description see http://www.afghanistan.gc.ca/canada-afghanistan/tbrief-seancedit/2009_06_23.aspx.

22 http://www.cefcom-comfec.forces.gc.ca/pa-ap/fs-ev/2009/09/18-eng.asp. peasantry. Conversely, the resettlement villages in Kenya, a much larger endeavour but copying significantly the Malayan program, were deserted shortly after that Emergency as land reform program unfolded. Development programs must therefore be attentive to local cultural norms and conditions if they are to succeed.

Another difficulty within the development domain is the argument that development is an inherent good, that is, any development delivered has value in and of itself. This is not necessarily true. In a counterinsurgency environment uncontrolled projects can unbalance or destabilize local relationships and may well exceed the local capacities to absorb the work. Development in the counterinsurgent environment may well be most useful in the construct suggested by David Kilcullen: as a sub-text for negotiations that assist in fostering viable local political relationships. ${ }^{23}$ Development is an important tool but it should not be bluntly applied as it occasionally is in pursuing simplistic needs perspectives.

Canada is facilitating development in Kandahar in a closely linked and layered fashion. It combines the longer-term orientation of the development team at the civilianized PRT with the more immediate activities of the military teams - the Civil-Military Cooperation (CIMIC) teams, the SET and the CMO. The military teams utilize Commander Contingency Fund projects after clear operations to rapidly deliver immediate improvements for the local population. Subsequently, the military teams concentrate on Quick Impact Projects, cashfor-work and others programs that support the progress of the campaign through the hold and the build phases while the PRT concentrates on economic and long-term development projects. This partnership is noteworthy for a number of reasons and is reflective of the value of the comprehensive approach in the Canadian experience. For example, the military can serve as the eyes and ears for the civilian elements of the PRT when risk levels are too high. Also, by planning together the projects supervised and implemented, the military can shape and prepare the environment for follow-on medium- and longterm projects to be delivered by the PRT. ${ }^{24}$ For both the civilian and military teams, projects are initiated only through and after consultation with local authorities, who often establish development councils, to ensure their desires are understood and their participation in the project secured. The development aspects of the Canadian campaign are closely intertwined and apply the comprehensive approach in an operational environment.

\section{Unity Starts in Ottawa}

For Canada, a unified and coordinated strategy must begin at home at the national level. The Government of Canada (GoC) is intently focussed on events in Afghanistan. Issues affecting the campaign are followed closely by the Cabinet. To monitor and report regularly on Canadian efforts in theatre a dedicated

23 Kilcullen, Accidental Guerrilla, 93-114

24 See Joint Task Force Afghanistan, "Engineer Support to Stability Operations (COIN) - Joint Task Force Afghanistan TFH 5-09," Theatre Lessons Report (TLR) 09/034 (Afghanistan 2009). 
Cabinet committee has been formed, the Cabinet Committee on Afghanistan. ${ }^{25}$ Task forces have been established across the GoC to manage the Canadian involvement. Overall direction and guidance is coordinated by the Afghan Task Force in the Privy Council Office. The Canadian International Development Agency (CIDA) similarly has a significant, large task force dedicated toward managing, planning and coordinating the delivery of the Canadian development objectives in theatre. Across the Canadian government departments and agencies, from the Royal Canadian Mounted Police, Corrections Service Canada, the Department of Justice and others, are actively involved and have deployed individuals to Afghanistan. For the Canadian military, the Canadian Forces Expeditionary Command (CEFCOM), the coordinator of all Canadian overseas military operations, oversees the campaign at the strategic level. ${ }^{26}$ Trained, deployable forces are generated for the CEFCOM mission by the services (Land, Air, Navy) and from with other functional areas of the Canadian Forces. Thus extensive, collective coordination and planning occurs on a continuous basis at the national level to effectively manage the Canadian involvement.

Canadian efforts, at least within our area of operation in Afghanistan, are bounded by a common intent developed through an evolving model of joined-up working. This model has iterated through a number of stages. The initial version was the 3D approach, a combination of defence, diplomacy and development; the integration and combination of the objectives of the three main outwardly looking departments: the Department of Foreign Affairs and International Trade (DFAIT), the Canadian International Development Agency (CIDA) and the Department of National Defence (DND). ${ }^{27}$ This concept was loosely based on an obvious recognition that individual institutions alone could not resolve the difficult challenges in Afghanistan and that they required methodologies for working together. This model migrated into a whole of government one as resources from across the Canadian government were dedicated to the fight. As more planners and implementers from outside government were brought into the process this model became the comprehensive approach. Within all these frameworks, the key components and application in Afghanistan stayed relatively consistent. First and foremost was the desire to put an Afghan face on practically any activity the Government of Canada undertook in support of the Afghan people. This has held true for the plans developed within Afghani ministries with the able coaching of Canadian Forces

25 http://www.afghanistan.gc.ca/canada-afghanistan/approach-approche/ccoaccsa.aspx.

26 See http://www.cefcom.forces.gc.ca/pa-ap/ops/itfafg-foiafg/index-eng.asp.

27 See Heather Hrychuk, "Lost in Translation: The Search for 3D in Afghanistan" (master's thesis, Royal Military College of Canada, 2007). members on the Strategic Advisor Team ${ }^{28}$ to practical each and every construction project, regardless of scale, that Canada has supported. A second issue is the adoption across participating departments of the common conceptual construct for success in counterinsurgency of shape, clear, build, and hold. ${ }^{29}$ This provides an important cornerstone for establishing a common dialogue that supports a shared common view. Finally, Canada largely remains committed to building capacity within Afghanistan to both support governance and to enable Afghanis to have better lives. This ability to craft a unifying intent and program has lent persistence and coherence to the Canadian program.

\section{Conclusion}

In Afghanistan by 2009 Canada did not lack for nails, the system functioned well. Canada had become proficient at counterinsurgency. Beside military operations there were a broad range of other activities contributing to the campaign. There were ongoing construction projects that provided employment for fighting-age youth to dissuade them from being attracted to the Taliban for financial reasons. Projects were layered with a view to filter them from short-term "cashfor-work" employment to longer-term opportunities. More in-depth situational awareness led to the crafting of campaigns that delivered on the wants and needs of the locals and thereby assisted in squeezing out overt Taliban influence. Protecting the population and separating them from the Taliban extremist elements has become the core focus. The nails existed and they were being driven home.

The Government of Canada not only brought its resources to bear but had realized the benefit and requirement for all actors to work together as partners, contributing where they might. At the national level this consisted of coordinating strategy through a whole of government mechanism supported by the other actors within a comprehensive approach. In theatre, Canadian efforts were closely integrated and intimately linked with planning and implementing partners. A variety of Canadian programs continue to build the capacities and capabilities of the Government of Afghanistan and aid in the maintenance of a safe and secure environment. At some point the Afghanis themselves must determine the legitimacy of their government and their willingness to be regulated by it, participate in it and support it - the keynote of success in counterinsurgency.

28 Lieutenant-Colonel Michel-Henri St.Louis, "The Strategic Advisory Team in Afghanistan - Part of the Canadian Comprehensive Approach to Stability Operations," Canadian Military Journal 9 (3): 58-67.

29 See Jean McCardle, The Province of Kandahar: Canadian Civilian Engagement (Presentation March 22, 2010). 